\title{
HUBUNGAN KEMAMPUAN MENGANALISIS TEKS OPINI \\ TERHADAP KEMAMPUAN MENULIS PARAGRAF \\ ARGUMENTASI SISWA KELAS XI SMA \\ NEGERI 1 ONAN RUNGGU TAHUN \\ PEMBELAJARAN 2017/2018
}

\author{
Kristiani Gultom \\ (kristingultom8@gmail.com) \\ Prof. Dr. Biner Ambarita, M.Pd.
}

\begin{abstract}
ABSTRAK
Penelitian ini bertujuan untuk mengetahui apakah ada hubungan antara kemampuan menganalisis teks opini dengan kemampuan menulis paragraf argumentasi pada siswa kelas XI SMA Negeri 1 Onan Runggu Tahun Pembelajaran 2017/2018.Populasi dari penelitian ini yaitu seluruh siswa/i SMA Negeri 1 Onan Runggu yang berjumlah 157 orang. Sampel dalam penelitian ini adalah siswa kelas XI IPS 1 yang berjumlah 32 orang siswa yang diambil dengan teknik random. Instrumen yang digunakan dalam penelitian ini adalah tes objektif yaitu tes pilihan berganda yang berjumlah 20 soal dan tes essai yaitu menulis paragraf argumentasi. Metode eksperimen yaitu dengan metode deskriptif korelasional.

Nilai rata-rata kemampuan menganalisis teks opini $=79,37$; standar deviasi $=8,00$; dan termasuk dalam kategori baik. Sedangkan nilai rata-rata kemampuan menulis paragraf argumentasi $=72,5$; standar deviasi $=4,53$. Setelah uji normalitas dan homogenitas, diperoleh $t_{h}$ sebesar $=2,557$, kemudian dikonsultasikan dengan $t_{\text {tabel }}$ pada taraf signifikan $5 \%$ sebesar $=1,697$. Karena $t_{h}$ yang diperoleh lebih besar dari $t_{\text {tabel}}$, yaitu 2,557>1,697 maka hipotesis nihil $\left(\mathrm{H}_{0}\right)$ ditolak dan hipotesis $\left(\mathrm{H}_{\mathrm{a}}\right)$ diterima.
\end{abstract}

Kata Kunci: Teks Opini, Paragraf Argumentasi

\section{PENDAHULUAN}

Pembelajaran bahasa Indonesia dalam ruang lingkup kebahasaan secara umum terdiri atas empat keterampilan berbahasa, yaitu keterampilan menyimak, keterampilan membaca, keterampilan berbicara dan keterampilan menulis.Sesuai dengan urutan pemerolehannya, keterampilan menulis merupakan keterampilan yang paling akhir untuk dikuasai.Namun, keterampilan menulis mempunyai 
peranan yang tak kalah penting dibandingkan dengan keterampilan berbahasa lainnya.

Secara tidak langsung menulis adalah bentuk komunikasi yang kita lakukan untuk menyampaikan gagasan melalui bahasa tulis.Sejalan dengan pendapat tersebut, Barus (2013:2) menyatakan bahwa menulis adalah rangkaian kegiatan mengungkapkan dan menyampaikan gagasan atau pikiran dengan bahasa tulis kepada pembaca sehingga pembaca dapat memahaminya.Dalam hal ini, orang yang melakukan kegiatan menulis disebut penulis. Hasil perbuatan itu disebut dengan tulisan, karangan atau karya tulis.Lalu yang memahami tulisan disebut pembaca.

Seiring dengan perkembangan informasi dan teknologi yang begitu pesat, keterampilan menulis akan menggeser pandangan tentang kecendikiaan seseorang. Media surat kabar berkembang begitu pesatnya. Fakta-fakta dan opini yang menarik bermunculan ke permukaan dan menarik untuk dikonsumsi oleh publik.Fakta-fakta menarik yang dikemas dalam sebuah berita memunculkan gagasan dari pembaca untuk berargumen dan dituangkan dalam bentuk tulisan. Tulisan dalam kolom surat kabar ini dikenal sebagai opini.

Tampubolon (1987:195) menyatakan bahwa opini adalah pandangan (pendapat) surat kabar (redaksi) atau penulis tertentu tentang sesuatu peristiwa, pikiran atau pandangan yang terjadi atau hidup dalam masyarakat. Opini yang merupakan pandangan surat kabar biasanya disajikan dalam bentuk tajuk rencana, komentar, pojok, dan karikatur, sedangkan opini yang merupakan pandangan penulis tertentu disajikan dalam bentuk karangan khusus (feature), surat pembaca, atau kolum (column).

Berdasarkan hasil wawancara peneliti dengan salah satu gurubahasa Indonesia di SMA Negeri 1 Onan Runggu yaitu bapak Donni Harapan Manik, S.Pd, dalam proses pembelajaran khususnya dalam pembelajaran mengenai teks opini, guru sering dihadapkan pada siswa yang kesulitan dalam menganalisis teks opini.Rendahnya kemampuan siswa dalam menganalisis teks opini pada siswa kelas XI disebabkan karena rendahnya tingkat keterbacaan teks opini dan juga faktor bacaan yang sulit. 
Berdasarkan Kurikulum Tingkat Satuan Pendidikan (KTSP) 2006 bidang studi Bahasa Indonesia SMA/MA, pembelajaran menulis khususnya menulis argumentasi dipelajari di kelas X semester II. Standar kompetensinya adalah mengungkapkan informasi melalui penulisan paragraf dan teks pidato. Kompetensi dasarnya adalah menulis gagasan untuk mendukung suatu pendapat dalam bentuk paragraf argumentatif. Menulis paragraf argumentasi merupakan kemampuan yang harus dikuasai siswa dengan menyajikan pemikiran terhadap fakta yang ada.

Menurut Tarigan (2013:3) menyatakan bahwa:

Menulis merupakan suatu keterampilan berbahasa yang dipergunakan untuk berkomunikasi secara tidak langsung, tidak secara tatap muka dengan orang lain. Menulis merupakan suatu kegiatan yang produktif dan ekspresif. Keterampilan menulis ini tidak akan datang secara otomatis, tetapi harus melalui latihan dan praktik yang teratur dan banyak.

Meskipun telah disadari bahwa keterampilan menulis sangat diperlukan dalam kehidupan modern, pada kenyataannya masih banyak siswa yang belum menguasai keterampilan menulis. Hal itu disebabkan oleh beberapa masalah yang berkaitan dengan rendahnya mutu pembelajaran keterampilan menulis. Salah satu keterampilan menulis adalah menulis paragraf argumentasi.

Berdasarkan hasil wawancara yang dilakukan peneliti dengan salah satu guru bahasa Indonesia di SMA Negeri 1 Onan Runggu yaitu bapak Donni Harapan Manik, S.Pd, mengatakan bahwa kemampuan menulis paragraf argumentasi siswa kelas XI SMA Negeri 1 Onan Runggu masih rendah, masih banyak siswa yang sulit menuangkan ide atau gagasan dalam menulis paragraf argumentasi, belum memahami tentang kaidah menulis paragraf yang baik, dan minimnya kosakata yang dikuasai.

Berdasarkan latar belakang di atas, maka penulis merumuskan penelitian dengan judul "Hubungan Kemampuan Menganalisis Teks Opini Terhadap Kemampuan Menulis Paragraf Argumentasi Siswa Kelas XI SMA Negeri 1 Onan Runggu Tahun Pembelajaran 2017/2018.” 


\section{METODE PENELITIAN}

Metode penelitan adalah cara untuk mencari kebenaran dengan mengumpulkan dan menganalisis data yang diperlukan guna mencapai tujuan penelitian. Metode penelitian ini memegang peranan penting dalam sebuah penelitian. Penentuan suatu metode tertentu harus disesuaikan dengan tujuan penelitian. Arikunto (2006:22) menyatakan "Metode penelitian merupakan struktur yang sangat penting karena berhasil tidaknya, ataupun tinggi rendahnya kualitas hasil penelitian sangat ditentukan oleh ketepatan dan memilih metode penelitian.” Metode yang digunakan dalam penelitian ini adalah metode deskriptif korelasional, yaitu dalam penelitian ini menjelaskan hubungan antar variabel. Dengan teknik ini diharapkan penulis dapat mengetahui hubungan antara variabel yang satu dengan variabel yang lain.

\section{HASIL DAN PEMBAHASAN}

Berdasarkan hasil penelitian yang dilakukan di kelas XI SMA Negeri 1 Onan Runggu Tahun Pembelajaran 2017/2018 diperoleh data sebagai berikut:

\section{Kemampuan Menganalisis Teks Opini (X) Siswa Kelas XI SMA Negeri 1 Onan Runggu Tahun Pembelajaran 2017/2018}

Tabel 1.Skor Kemampuan Menganalisis Teks opini (X)

\begin{tabular}{|c|c|c|c|}
\hline No & Nama Siswa & $X$ & $X^{2}$ \\
\hline 1 & Adi Putra Manik & 70 & 4900 \\
\hline 2 & Andi Abet Lumbantoruan & 80 & 6400 \\
\hline 3 & Andikah Gultom & 75 & 5625 \\
\hline 4 & Andre Gultom & 75 & 5625 \\
\hline 5 & Arjunawan Pandiangan & 80 & 6400 \\
\hline 6 & Coly Misrun Samosir & 80 & 6400 \\
\hline 7 & Dinar Forlina Sitanggang & 90 & 8100 \\
\hline 8 & Doruli Gultom & 90 & 8100 \\
\hline 9 & Edianto Gultom & 70 & 4900 \\
\hline 10 & Elisabeth Pakpahan & 75 & 5625 \\
\hline 11 & Enjelina Gultom & 65 & 4225 \\
\hline 12 & Erwan Yusuf R. Simbolon & 80 & 6400 \\
\hline 13 & Gilbert Samosir & 85 & 7225 \\
\hline 14 & Hatoguan Parhusip & 85 & 7225 \\
\hline 15 & Herianto Gultom & 75 & 5625 \\
\hline
\end{tabular}




\begin{tabular}{|l|c|c|c|}
\hline 16 & Jeremia Samosir & 75 & 5625 \\
\hline 17 & Lukas Lambok Sinaga & 70 & 4900 \\
\hline 18 & Mariana M. Gultom & 80 & 6400 \\
\hline 19 & Mario J. Pakpahan & 85 & 7225 \\
\hline 20 & Novalina E. Sitinjak & 70 & 4900 \\
\hline 21 & Perdi Lumbanraja & 65 & 4225 \\
\hline 22 & Rinalija T. Harianja & 85 & 7225 \\
\hline 23 & Rini Afriani Gultom & 90 & 8100 \\
\hline 24 & Rino Gultom & 95 & 9025 \\
\hline 25 & Riski K. Samosir & 90 & 8100 \\
\hline 26 & Romoppo E. Gultom & 70 & 4900 \\
\hline 27 & Rosaridepi Hutabalian & 85 & 7225 \\
\hline 28 & Runi Arta Sitinjak & 80 & 6400 \\
\hline 29 & Suito Pandiangan & 80 & 6400 \\
\hline 30 & Thesalonika Samosir & 80 & 6400 \\
\hline 31 & Tua Joko Sitinjak & 85 & 7225 \\
\hline 32 & Wempy M. Hutagaol & 80 & 6400 \\
\hline & Jumlah & 2540 & 203600 \\
\hline
\end{tabular}

Berdasarkan tabel di atas terlihat bahwa data skor tertinggi kemampuan menganalisis teks opini siswa adalah 95 dan skor terendah adalah 65 dengan ratarata 79,37 .

Untuk mengetahui kemampuan menganalisis digunakan standar skor menurut Arikunto (2006:74) sebagai berikut.

Tabel 2.Standar Skor Menurut Arikunto

\begin{tabular}{|c|c|c|c|}
\hline No & Skor Penilaian & Kategori & Kategori Huruf \\
\hline 1 & Skor 85-100 & Sangat baik & A \\
\hline 2 & Skor 70-84 & Baik & B \\
\hline 3 & Skor 55-69 & Cukup & C \\
\hline 4 & Skor 40-45 & Kurang & E \\
\hline 5 & Skor 0-39 & Sangat kurang & D \\
\hline
\end{tabular}

Berdasarkan standar skor di atas, maka terdapat 11 siswa dalam kategori sangat baik, 19 siswa dalam kategori baik, dan 2 siswa dalam kategori cukup. Dengan demikian dapat disimpulkan bahwa kemampuan menganalisis teks opini siswa kelas XI SMA Negeri 1 Onan Runggu tergolong kategori baik. 
2. Kemampuan Menulis Paragraf Argumentasi (Y) Siswa Kelas XI SMA Negeri 1 Onan Runggu Tahun Pembelajaran 2017/2018

Tabel 3.Skor Kemampuan Menulis Paragraf Argumentasi (Y)

\begin{tabular}{|c|c|c|c|}
\hline No & Nama Siswa & $\mathbf{Y}$ & $\mathbf{Y}^{2}$ \\
\hline 1 & Adi Putra Manik & 70 & 4900 \\
\hline 2 & Andi A. Lumbantoruan & 70 & 4900 \\
\hline 3 & Andikah Gultom & 70 & 4900 \\
\hline 4 & Andre Gultom & 70 & 4900 \\
\hline 5 & Arjunawan Pandiangan & 80 & 6400 \\
\hline 6 & Coly Misrun Samosir & 80 & 6400 \\
\hline 7 & Dinar Forlina Sitanggang & 75 & 5625 \\
\hline 8 & Doruli Gultom & 70 & 4900 \\
\hline 9 & Edianto Gultom & 75 & 5625 \\
\hline 10 & Elisabeth Pakpahan & 80 & 6400 \\
\hline 11 & Enjelina Gultom & 80 & 6400 \\
\hline 12 & Erwan Y.R. Simbolon & 75 & 5625 \\
\hline 13 & Gilbert Samosir & 70 & 4900 \\
\hline 14 & Hatoguan Parhusip & 75 & 5625 \\
\hline 15 & Herianto Gultom & 70 & 4900 \\
\hline 16 & Jeremia Samosir & 70 & 4900 \\
\hline 17 & Lukas L. Sinaga & 70 & 4900 \\
\hline 18 & Mariana M. Gultom & 60 & 3600 \\
\hline 19 & Mario J. Pakpahan & 70 & 4900 \\
\hline 20 & Novalina E. Sitinjak & 70 & 4900 \\
\hline 21 & Perdi Lumbanraja & 80 & 6400 \\
\hline 22 & Rinalija Y. Harianja & 75 & 5625 \\
\hline 23 & Rini Afriani Gultom & 70 & 4900 \\
\hline 24 & Rino Gultom & 75 & 5625 \\
\hline 25 & Riski K. Samosir & 85 & 7225 \\
\hline 26 & Romoppo E. Gultom & 70 & 4900 \\
\hline 27 & Rosaridepi Hutabalian & 70 & 4900 \\
\hline 28 & Runi Arta Sitinjak & 70 & 4900 \\
\hline 29 & Suito Pandiangan & 70 & 4900 \\
\hline 30 & Thesalonika Samosir & 70 & 4900 \\
\hline 31 & Tua joko Sitinjak & 70 & 4900 \\
\hline 32 & Wempy M. Hutagaol & 75 & 5625 \\
\hline \multicolumn{2}{|c|}{ Jumlah } & 2320 & 168900 \\
\hline
\end{tabular}

Berdasarkan data dalam tabel di atas terlihat bahwa data skor tertinggi kemampuan menganalisis teks opini siswa adalah 85 dan skor terendah adalah 60 dengan rata-rata 72,5 . 
Untuk mengetahui kemampuan menulis paragraf argumentasi digunakan standar skor menurut Arikunto (2006:74) sebagai berikut.

Tabel 4. Standar Skor Menurut Arikunto

\begin{tabular}{|c|c|c|c|}
\hline No & Skor Penilaian & Kategori & Kategori Huruf \\
\hline 1 & Skor $85-100$ & Sangat baik & A \\
\hline 2 & Skor 70-84 & Baik & B \\
\hline 3 & Skor 55-69 & Cukup & D \\
\hline 4 & Skor 40-45 & Kurang & E \\
\hline 5 & Skor 0-39 & Sangat kurang & \\
\hline
\end{tabular}

Berdasarkan standar skor di atas, maka terdapat 1 siswa dalam kategori sangat baik, 30 siswa dalam kategori baik, dan 1 siswa dalam kategori cukup. Dengan demikian dapat disimpulkan bahwa kemampuan menulis paragraf argumentasi siswa kelas XI SMA Negeri 1 Onan Runggu tergolong kategori baik.

\section{Hubungan Kemampuan Menganalisis Teks Opini (X) dengan Kemampuan Menulis Paragraf Argumentasi (Y)}

Setelah $\mathrm{t}_{0}$ diperoleh yaitu sebesar 2,557, selanjutnya dikonsultasikan dengan $t_{\text {tabel }}$ pada taraf signifikan 5\% yaitu sebesar 1,697. Dengan membandingkan antara $t_{0}$ dengan $t_{\text {tabel }}$ diperoleh $t_{0}$ lebih besar dari $t_{\text {tabel }}$ yaitu 2,557>1,697, maka hipotesis nihil $\left(\mathrm{H}_{0}\right)$ ditolak dan hipotesis $\left(\mathrm{H}_{\mathrm{a}}\right)$ diterima. Hal ini membuktikan bahwa ada hubungan antara kemampuan menganalisis teks opini dengan kemampuan menulis paragraf argumentasi siswa kelas XI SMA N 1 Onan Runggu Tahun Pembelajaran 2017/2018.

\section{Pembahasan Hasil Penelitian}

1. Kemampuan Menganalisis Teks Opini (X) Siswa Kelas XI SMA Negeri 1 Onan Runggu Tahun Pembelajaran 2017/2018

Kemampuan menganalisis teks opini siswa kelas XI SMA Negeri 1 Onan Runggu Tahun Pembelajaran 2017/2018 termasuk dalam kategori baik dengan rata-rata 79,37. Kemampuan menganalisis teks opini kelas XI SMA N 1 Onan 
Runggu dikatakan baik karena terlihat dari data hasil penelitian yang menunjukkan bahwa siswa sudah mampu menganalisis teks opini yang dinilai dari tiga aspek penilaian, yaitu aspek isi, tema, dan kosa kata. Rata-rata aspek penilaian isi yaitu 52,18, rata-rata aspek penilaian tema yaitu 15,46 dan rata-rata aspek penilaian kosa kata yaitu 11,70. Berdasarkan lima kriteria untuk menentukan tingkat penguasaan siswa, maka terdapat 11 siswa dalam kategori sangat baik, 19 siswa dalam kategori baik, dan 2 siswa dalam kategori cukup yang disebabkan oleh kurangnya kosa kata siswa dalam menganalisis teks opini. Dari hasil analisis uji normalitas, kemampuan menganalisis teks opini (X) setelah dikonsultasikan dengan $1_{\text {tabel }}$ pada taraf signifikan $5 \%$ maka memiliki nilai $l_{\text {hitung }}<$ $1_{\text {tabel }}$ yaitu $0,1283<0,1568$ ataupun data berdistribusi normal.

\section{Kemampuan Menulis Paragraf Argumentasi (Y) Siswa Kelas XI SMA Negeri 1 Onan Runggu Tahun Pembelajaran 2017/2018}

Kemampuan menulis paragraf argumentasi siswa kelas XI SMA Negeri 1 Onan Runggu Tahun Pembelajaran 2017/2018 termasuk dalam kategori baik dengan rata-rata 72,5. Kemampuan menulis paragraf argumentasi siswa kelas XI SMA N 1 Onan Runggu dikatakan baik yaitu terlihat dari data hasil penelitian yang menunjukkan bahwa siswa sudah mampu menulis paragraf argumentasi yang dinilai dari 5 aspek penilaian, yaitu aspek isi gagasan, ciri paragraf argumentasi, diksi, ejaan, dan aspek penilaian koherensi. Rata-rata aspek penilaian isi gagasan yaitu 19,06, rata-rata aspek penilaian ciri paragraf argumentasi yaitu 9,68, rata-rata aspek penilaian diksi yaitu 18,75, rata-rata aspek penilaian ejaan yaitu 9,68 dan rata-rata aspek penilaian koherensi yaitu 15,31. Aspek penilaian yang paling rendah dalam kemampuan menulis paragraf argumentasi menurut data hasil penelitian yaitu aspek ciri paragraf argumentasi dan aspek ejaan. Berdasarkan lima kriteria untuk menentukan tingkat penguasaan siswa, maka terdapat 1 siswa dalam kategori sangat baik, 30 siswa dalam kategori baik, dan 1 siswa dalam kategori cukup disebabkan karena kurangnya kemampuan menulis paragraf argumentasi. Dari hasil analisis uji normalitas, kemampuan menulis paragraf argumentasi (Y) setelah dikonsultasikan dengan $1_{\text {tabel }}$ pada taraf 
signifikan $5 \%$ maka memiliki nilai $1_{\text {hitung }}<1_{\text {tabel }}$ yaitu $0,1342<0,1568$ ataupun data berdistribusi normal.

\section{Hubungan Kemampuan Menganalisis Teks Opini (X) dengan Kemampuan Menulis Paragraf Argumentasi (Y)}

Hubungan antara kemampuan menganalisis teks opini dengan kemampuan menulis paragraf argumentasi siswa kelas XI SMA Negeri 1 Onan Runggu Tahun Pembelajaran 2017/2018 hubungannya yaitu cukup berarti. Diperoleh $\mathbf{r}_{\text {hitung }}=$ 0,342 sedangkan $r_{\text {tabel }}$ pada taraf signifikan 0,05 dengan $\mathrm{N}=32$ sebesar 0,349 . Karena $r_{\text {hitung }}>r_{\text {tabel }}(0,423>0,349)$ maka dapat disimpulkan bahwa korelasi antara kemampuan menganalisis teks opini dengan kemampuan menulis paragraf argumentasi hubungannya cukup berarti. Hal ini berarti bahwa apabila kemampuan menganalisis teks opini siswa kelas XI SMA Negeri 1 Onan Runggu Tahun Pembelajaran 2017/2018 baik maka kemampuan menulis paragraf argumentasi akan baik juga. Berdasarkan pengujian hipotesis yang telah dilakukan dengan menggunakan uji $\mathrm{t}$ diperoleh $\mathrm{t}_{\text {hitung }}$ sebesar 2,557 sedangkan nilai $\mathrm{t}_{\text {tabel }}$ sebesar 1,697 sehingga $t_{\text {hitung }}>t_{\text {tabel }}(2,557>1,697)$. Dengan demikian maka hipotesis dalam penelitian ini menyatakan bahwa "terdapat hubungan yang positif antara kemampuan menganalisis teks opini dengan kemampuan menulis paragraf argumentasi oleh siswa kelas XI SMA Negeri 1 Onan Runggu Tahun Pembelajaran 2017/2018" dapat diterima $\left(\mathrm{H}_{\mathrm{a}}\right)$ dan hipotesis nihil $\left(\mathrm{H}_{0}\right)$ ditolak.

\section{PENUTUP}

Kemampuan menganalisis teks opini siswa kelas XI SMA Negeri 1 Onan Runggu Tahun Pembelajaran 2017/2018 memiliki nilai rata-rata sebesar 79,37 yang termasuk dalam kategori baik.

Kemampuan menulis paragraf argumentasi siswa kelas XI SMA Negeri 1 Onan Runggu memiliki nilai rata-rata sebesar 72,5 yang termasuk dalam kategori baik.

Terdapat hubungan antara kemampuan menganalisis teks opini dengan kemampuan menulis paragraf argumentasi oleh siswa kelas XI SMA Negeri 1 
Onan Runggu Tahun Pembelajaran 2017/2018. Diperoleh $r_{\text {hitung }}=0,423$ dan $r_{\text {tabel }}$ pada taraf signifikan 0,05 dengan $\mathrm{N}=32$ sebesar 0,349 . Karena $r_{\text {hitung }}>r_{\text {tabel }}(0,423$ $>0,349$ ) maka dapat disimpulkan bahwa korelasi antara kemampuan menganalisis teks opini dengan kemampuan menulis paragraf argumentasi hubungannya cukup berarti.

\section{Saran}

Kemampuan menganalisis teks opini di kelas XI SMA Negeri 1 Onan Runggu termasuk dalam kategori baik.Namun walaupun demikian kemampuan menganalisis teks opini harus senantiasa ditingkatkan sehingga siswa dapat mengetahui teks opini tersebut.

Kemampuan menulis paragraf argumentasi termasuk dalam kategori baik, namun hendaknya dapat lebih ditingkatkan lagi dengan banyak membaca dan menulis paragraf argumentasi sehingga kemampuan menulis paragraf argumentasi pun akan semakin meningkat. 


\section{DAFTAR PUSTAKA}

Arikunto, Suharsimi. 2006. Prosedur Penelitian Suatu Pendekatan Praktek.

Jakarta: Rineka Cipta.

Barus, Sanggup. 2013. Penulisan Karya Tulis. Jakarta: Halaman Moeka.

Tampubolon.1987 (Cetakan Terakhir).Kemampuan Membaca Teknik Membaca

Efektif dan Efisien. Bandung: Angkasa.

Tarigan, H.G. 2013.Menulis Sebagai Suatu Keterampilan Berbahasa. Bandung: Angkasa. 